\title{
FEATURES OF FORMATION DEVELOPING EDUCATIONAL ENVIRONMENT IN THE CONDITIONS OF STANDARDIZATION OF PRIMARY EDUCATION OF UKRAINE
}

\author{
SVITLANA SMOLIUK
}

\begin{abstract}
In the article on the basis of the scientific literature study, the peculiarities of the formation of the educational environment in the modern elementary school are highlighted. The basic components (informational, social-psychological, cultural-educational and material-technical) as well as components of innovative educational environment of elementary school (spatial, informative, communicative) are substantiated. In the structure of the educational environment of the school, the author identifies the following functions: didactic-educational, informationdeveloping, coordinative, adaptive-emotional, socio-cultural, communicative, integrative, which ensure the integrity and systemic functioning of the simulated environment of the elementary school. The basic aspects of psychological and pedagogical expertise of the developing educational environment are determined in the paper. The stages of activity of all the subjects of educationaleducational interaction (students, teachers, parents) in the subject-content functioning of the developing educational environment of primary school are singled out.
\end{abstract}

Keywords: developmental educational environment, elementary school, development of personality of junior schoolchild, psychological and pedagogical examination, adaptation, socialization.

\section{INTRODUCTION}

In today's conditions of reforming the educational system of Ukraine, the problems of the development of the student personality in an educational institution environment, preparation for independent study and self-improvement, individualization and differentiation of the pedagogical process, increase of its efficiency by introducing educational innovations are particularly acute. Therefore, the problem of designing a positive development environment for elementary school is updated, taking into account the progressive achievements of the historical and pedagogical heritage of foreign and domestic scientists.

The problem of formation of a developing educational environment in educational institutions of different types, including elementary school, in various aspects is reflected in the scientific works of the teachers of the past and the present periods of time. For our research important are the ideas on sensory development of the younger schoolchild (Y. Komensky, I. Pestalozzi, K. Ushinsky, V. Sukhomlinsky, etc.), the development of emotional and sensory sphere of children (I. Haman, R. Gibson), stimulation 
of cognitive interests of students (N. Bibik, O. Savchenko), personally oriented education and education (Sh. Amonashvili, I. Bekh, I. Yakimanska, etc.), pedagogical creativity (N. Kichuk, S. Sysoeva, R. Skulsky) socio-cultural development of children and youth, ethnogenesis in elementary school (O. Budnyk, H. Vasyanovich, M. Stelmakhovych, V. Sukhomlinsky); implementation of the developmental function of the educational process in the elementary classes (V. Bondar, O. Matvienko, O. Otych, L. Khomych, etc.).

The purpose of the article is to substantiate the peculiarities of the formation of a developing educational environment of elementary school at the reforming stage of Ukrainian education.

\section{ANALYSIS AND DISCUSSION}

On the basis of the analysis of historical and pedagogical literature, we arrive at the conclusion that at the end of the twentieth century researches especially focus on the problem of the comprehensive development of personality, serving as the main goal of education and education. It was in the late $1980^{\mathrm{s}}$ and $1990^{\mathrm{s}}$ that the following foreign scientific trends were relevant to the person and its development: behaviorism, pedagogy of culture, psychoanalytic pedagogy, cognitive psychology and humanistic pedagogy, serving as guiding points in shaping the developing educational environment of a modern elementary school. These most pronounced five domains, which dominated the national pedagogical science of the 1990s, emphasize the peculiarities of this or that aspect of personality for its in-depth study and understanding. At the same time, on the basis of their analysis, the key is the provision that the development of the student's personality takes place through direct interaction in two planes: the influence of the environment on the personality and personality' impact on the surrounding world.

In the discourse of our study, especially valuable is the doctrine that as a result of this interaction the individuality is formed (V. Okon) [8, p. 71] (Fig. 1). The author characterizes the personality from a receptive-adaptive and active-creative position. Thus, at the stage of the student's entry into the educational environment of the school, its initial adaptation takes place. Although at this stage for some time its relative stability and opposition to external influence still remains. Consequently, the variability factors contribute to certain changes in the environment or the adaptation process of the student to the existing conditions. Thus, the interaction of man and environment (in our case, the student and educational environment of the school) results in the development of personal qualities, experience formation in various activities. And the highest level of such interaction is the creative personality, capable of self-development and self-improvement, transformation of the world on the basis of knowledge and constant contacts with other people.

The adaptation and socialization processes in the educational environment of the school is considered not only in the context of the occurrence or "habituation" of the individual to certain conditions of life, daily routine, classroom students and teachers, but also to a lesser extent to the content of educational activity, teaching style, forms and methods of education, the nature of pedagogical communication, etc. At the moment of coming to school among the first-graders in their interaction with the new educational environment, a dynamic equilibrium is violated; the actual change of the environment requires the mastering of existing moral norms of behavior, traditions, stimulates the activation of communicative activity. Due to the successful adaptation of the child to the conditions of primary school, when everything new for it becomes a common occurrence, the system of acquired knowledge, skills, behavioral habits, habits is fixed in the so-called higher level of socialization, which allows its free functioning in the existing environment. It is the processes of adaptation and socialization that are determinants of the successful development of a junior student in the process of education and upbringing. 


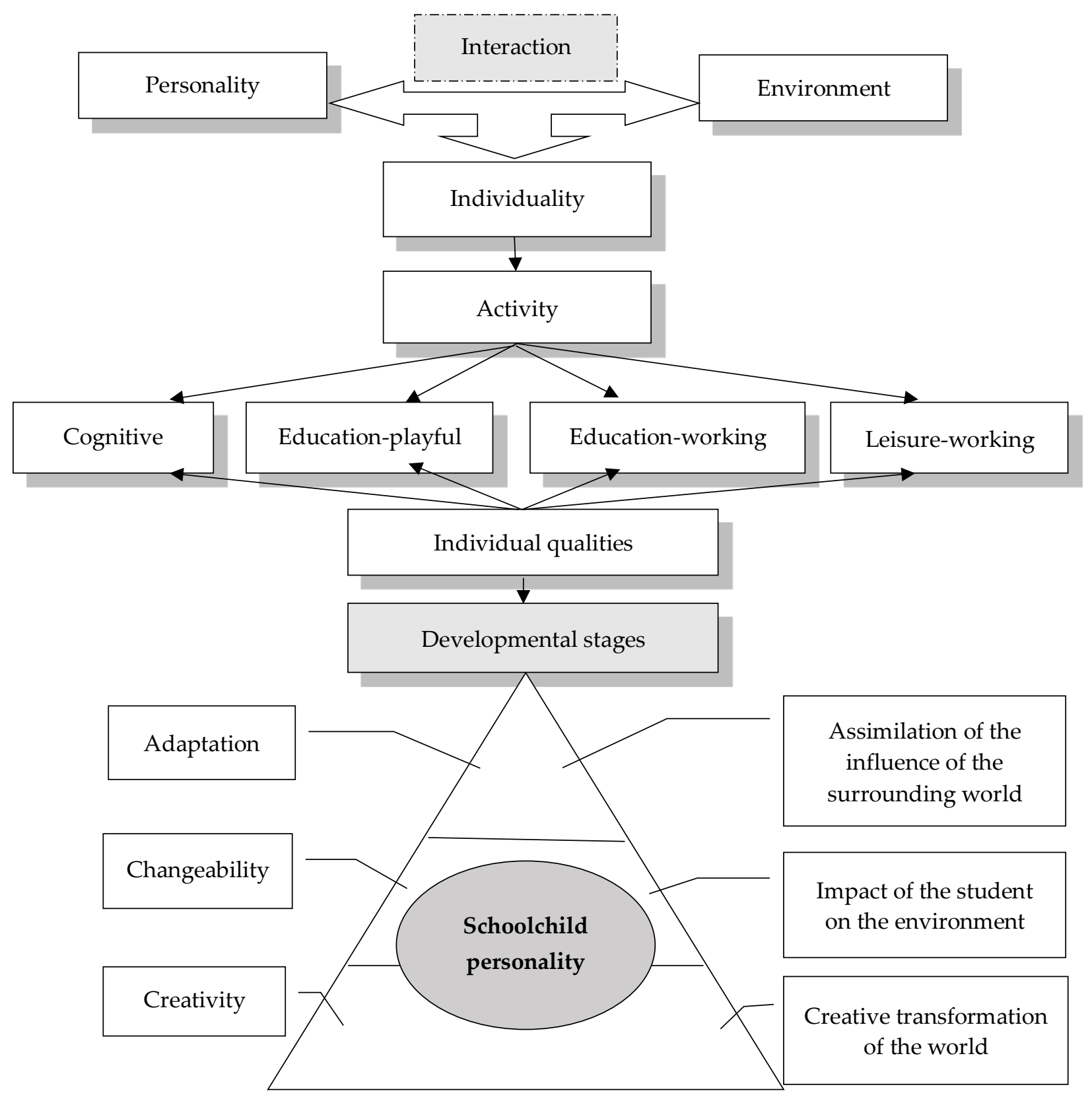

Fig. 1. Stages of personality development of the student in the environment.

On the basis of the theory of pedagogical hermeneutics, we arrive at a conclusion on the significance of the subject-subjective interaction between students, teachers and parents, especially during the period of adaptation in the first year of study through understanding (mutual understanding) (Fig. 2). 


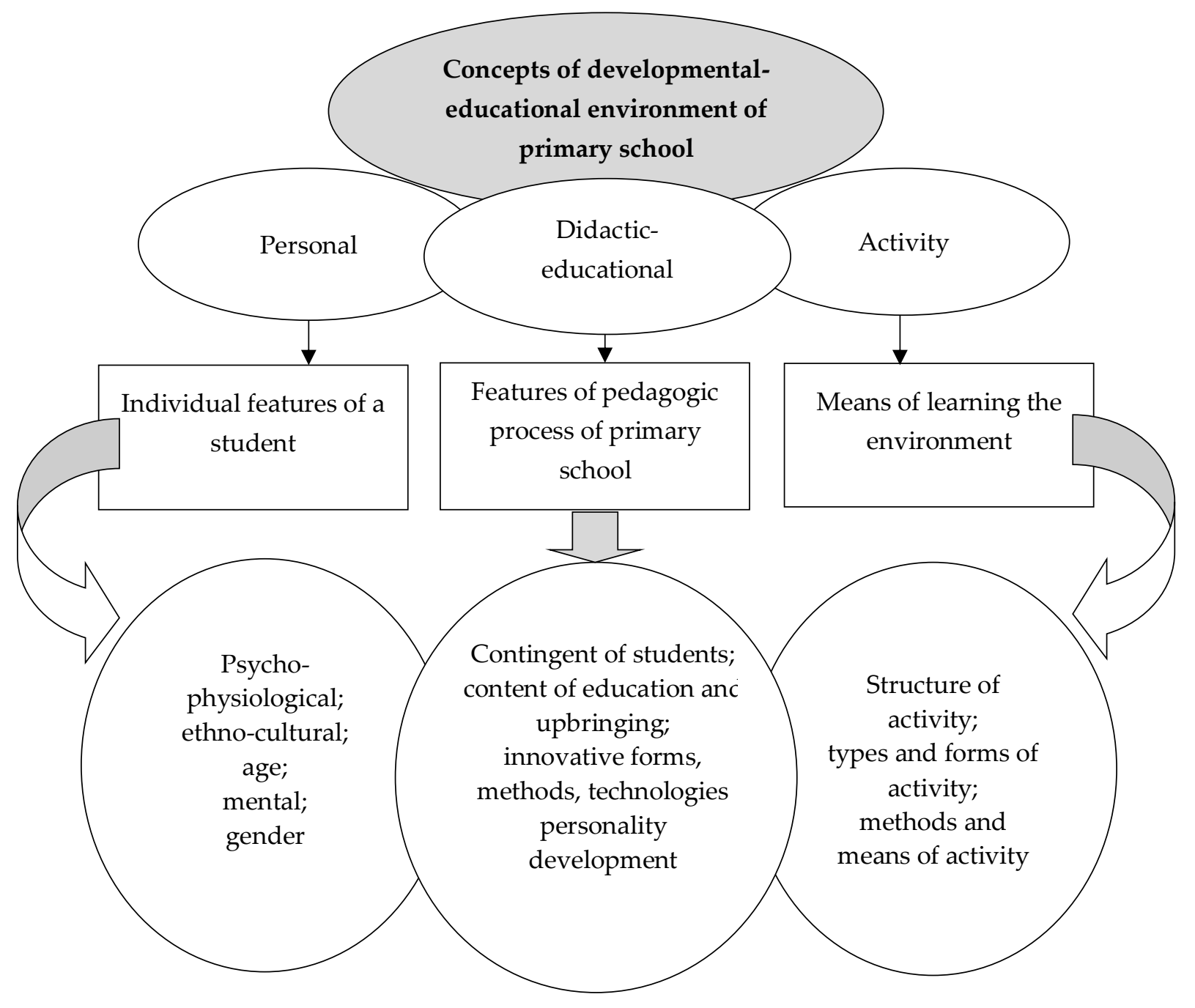

Fig. 2. Adapted graphic interpretation of concepts interaction of the developing educational environment (by A. Tsymbalaru).

Taking into account the personality-activity approach as a methodological principle, we carry out modeling of the developing educational environment of a modern elementary school, the important task of which is to develop the student's creative personality, his cognitive abilities and abilities in the process of education and upbringing. So, we highlight the following concepts of a developing educational environment: didactic and educational, personal and activity.

At the same time, it is extremely important to take into account the leading ideas of the outstanding teacher of the last century V. Sukhomlynskyi, who regarded creativity as an integral part of the educational process, since the children at Pavlyshska school had learned to make tales long before they learned to write. They painted, wrote poems and tasks, etc. [10, p. 71]. Actually the teacher arranged a creative environment of the school, aimed at the harmonious development of the student's personality in the process of education and upbringing. The modern system of developmental education (O. Dusavytsky, O. Savchenko, etc.) presupposes its orientation towards the development of the student's personality, its talents in the educational process of the school. So, according to O. Dusavytsky, the program of developmental education focuses on the so-called refusal of conditional division of students according to their intellectual abilities on the basis of the test; the identification of giftedness on the basis of the definition of the personal and mental development of children, in particular the development of giftedness in the process of developmental learning, and the definition of effectiveness of teaching children in the conditions of traditional and developmental education [4, p. 24-27]. 
The main objective of creating a developing educational environment in a modern primary school is to provide high-quality educational services to students at the initial stage of education, timely identification of giftedness, development of their abilities and self-development. In this context, we consider the developing educational environment as a systematic object of pedagogical modeling, which is accompanied by the separation of certain its structural components.

Thus, simulation of a developing educational environment is a complex multilevel process that involves a schematic (simplified) image of its main components based on a combination of implementation of various functions of the professional activity of the teacher.

As evidenced by the analysis of scientific sources, in pedagogical science there is no clear unambiguous definition of the structure of this phenomenon.

O. Budnyk's modeling of the social and educational environment of an educational institution is based on the following elements: informational, social-psychological, cultural-educational and material-technical [2, p. 317-318].

Summarizing the scientific works of V. Sukhomlynskyi, V. Meleshko characterized the components of the educational environment of the Pavlyska school as follows [6]:

- spatial - organization of the living space of schoolchildren: a school garden, a greenhouse, a preschool plot, a radio laboratory, a methodical office, workshops, a museum, places with books for parents, works of fine arts, a library, a fairy tale room, a space for a young ethnographers, an alley of youth, exhibitions of children's drawings, an area map marked with findings of young ethnographers, a panel, a chess table, etc.;

- content - the concept of learning was aimed at stimulating cognitive abilities of students and formation of self-education skills, joy of cognition, success in learning, intellectual and spiritual growth. The concept of education was based on the formation of society citizens with highly moral, person upbringing with a pure and noble soul; affirmation of love for people-workers; formation of persistent beliefs, etc. (the main forms of organization of the pedagogical process: conversations, meetings, lessons-reflections, lessons-considerations, lessons of thinking in nature, compilation of fairy tales, works, excursions, hiking trips, individual reading, research work, journeys to the world of art, competitions in classrooms of young circles of radio engineers, etc.);

- communicative - the domination of a democratic style of psycho-pedagogical communication, based on the principles of interaction, cooperation, mutual respect, mutual understanding; communication with nature (main forms and methods of pedagogical interaction: a school of pedagogical culture, recommendations for a teacher, etc.).

In the structure of the innovative educational environment in the higher pedagogical school O. Shapran and Yu. Shapran determine the following components: logistical, technological and subjective-social [11].

On the basis of the analysis of scientific and pedagogical works on the studied problem (O. Budnyk, V. Meleshko, O. Savchenko, O. Shapran, Yu. Shapran, O. Yaroshynska, V. Yasvin, etc.), taking into account the system approach, we single out such components of developmental educational environment in the modern primary school:

- information - availability of modern normative, educational, organizational and technological support of the process of formation of educational developmental environment of primary school;

- psychological - taking into account individual psychological peculiarities of student development in educational process, orientation on spiritual and moral values in behavior and activity, formation of adequate perception of network environment, communicative culture of participants in pedagogical process, etc.;

- space-objective - consideration of elements of object-developing design in the interior of the school of the first degree, organization of space structure of the environment, including its heterogeneity and complexity, interconnectedness of different functional spaces (zones), mobility and controllability of the medium as a means of training and developing communication of the teacher, students and their parents; availability of modern multimedia, audio, video facilities of educational and developmental purpose; 
- cultural and educational - pedagogical competence of participants in the educational process of the primary school, covering the content, forms, methods, innovative technologies for the realization of the tasks of development and self-development of the growing person on the principles of social culture; orientation on social order, regional needs, cultural potential of the region.

For example, the space-objective component of the school environment includes: natural and cultural landscapes, physical culture and health facilities, school canteens (cafe), library, video library, design studio, school museum, music and choreography studio, computer classes, games complexes, etc., as well as material and technical support of the educational process in the classroom: educationalmethodical complexes of teaching individual subjects, a space for extracurricular activities children's reading, a space of wildlife, multimedia equipment, etc.

In the structure of the educational environment of the school we distinguish the following main functions: didactic-educational, information-developing, coordination, adaptive-emotional, sociocultural, communication, integration, which ensure the integrity and systematic functioning of the simulated environment of the primary school.

In the conditions of standardization of primary education, the question arises about the modeling of the environment capable of ensuring the student's effective development. According to N. Syrovetnyk, on the basis of modeling, the design of the educational environment of the primary school is carried out in three stages: the stage of formation (characterized by the development of the concept and program of development, first of all, the spirituality of the primary school student), the stage of functioning (creation of the necessary conditions for the effective functioning of the corresponding environment and ensuring proper interaction between participants in the educational process: students, parents, teachers, educators, etc.) and the stage of improvement (constant search for effective means, innovative forms and methods to improve the learning environment created according to the needs, interests and opportunities and creative development of children) [9].

In the context of pedagogical hermeneutics regarding the simulation of a developing educational environment of primary school and its management, we value the experience of the experimentalistteacher of the investigated period Sh. Amonashvili. Positive pedagogical effect in the educational process is very difficult to achieve if there is no mutual understanding, empathy, mutual knowledge. "If I try to understand children, they will also want to understand me and imitate me, and my pedagogical life will not contradict their life", the scientist says [1, p. 96].

As a Ukrainian researcher V. Sukhomlynskyi wrote that the teacher should rise to the level of a child to understand it, and the Georgian teacher Sh. Amonashvili believes: "In order for children to take me into my world, I must come to them with my childhood as a pledge the fact that I am not a stranger", because the teacher must enter the lives of his students only through returning to his childhood [1, p. 96]. Therefore, in today's primary school, it is extremely important to achieve understanding among all participants in the pedagogical process, emotional and psychological comfort, cooperation, harmony for the formation of a positive development environment in accordance with the requirements of the society and the requests and preferences of each child.

The results of a pedagogical examination testify to the effectiveness of a developing educational environment. Expertise is a "holistic scientific-cognitive or qualification procedure, which involves a comprehensive contextual study of the phenomenon, process, conditions of existence or course of events", which is the subject of the study [5, p. 256]. Accordingly, pedagogical expertise is "a comprehensive study of the peculiarities and conditions of the functioning of the components and elements of pedagogical influence, pedagogical interaction, pedagogical process" [5, p. 256].

Extrapolating psychological and pedagogical expertise in the direction of developing educational environment, we define the following aspects:

- intellectual saturation of the educational environment by analyzing the formal results based on the control of students' learning achievements in accordance with certain content lines;

- studying school documentation (registers, notebooks, diaries, reports) and creative work of students (works, drawings, products, wallpapers, photos); 
- analysis of the dynamics of development of junior schoolchildren: anatomical and physiological development, development of cognitive sphere (attention, thinking, memory), formation of personal qualities (motivation to study, organizational skills, leadership skills, etc.) through the use of psychodiagnostic techniques, trainings, etc.;

- characteristics of the developmental educational environment of the primary school, in particular its orientation to meeting the needs and abilities of the student in mastering new competencies, socio-cultural values and transforming them into persistent personal features;

- identification of the pedagogical management style of the organization of the developing educational environment and the nature of the personal interaction of its subjects on the basis of observations, conversations with pupils, teachers, parents, and school administration.

\section{CONCLUSIONS}

The main criterion for the formation of a developing educational environment during the reform of Ukrainian education is the ability of this environment to provide appropriate conditions for the personal self-development of all subjects in the pedagogical process [7].

The effectiveness of the substantive and content functioning of the developmental educational environment of the primary school includes the activities of all subjects of educational interaction (students, teachers, parents) according to the separate stages:

1) the stage of entry into the development-oriented educational environment, the primary adaptation to the style of organization and management;

2) the stage of mastering the structural components of this environment and the nature of the interaction of participants in the pedagogical process;

3) the stage of solving educational and developmental problems, difficult situations of the mostly standardized type;

4) the stage of solving creative, problem-search tasks;

5) the stage of self-development and self-presentation.

The integrity of the simulated developmental educational environment is ensured by a complex of organizational and pedagogical conditions that, according to our belief, contribute to the development of cognitive activity and student's personal freedom: psychological and pedagogical support of students in the process of their adaptation; creation of an intellectually and emotionally rich environment by establishing a subject-subject interaction in a pedagogical process between a teacher and a student, creating an atmosphere of creativity; the potential use of the content of primary education for the student's personal development; taking into account the typical multifaceted educational environment of the primary school for the harmonious development of the student's personality; formation of the professional readiness of future teachers to create an effective educational environment in a modern primary school, taking into account the progressive historical and pedagogical experience.

\section{REFERENCES}

[1] Amonashvili Sh.A. How do you live, kids? Enlightment, Moscow, 1986. (in Russian)

[2] Budnyk O. Professional training of primary school teachers to social and educational activities: Theory and Practice (monograph). "Seredniak T.K.", Dnipropetrovsk, 2014. (in Ukrainian)

[3] Budnyk O. Education of pupil's personality in sociocultural environment of modern school. Scientific Bulletin of Chetm, 1 (2016), 133-142.

[4] Dusavytskyi A.K. A gifted child and developmental learning. Gifted child, 5-6 (1998), 24-27. (in Russian)

[5] Manokha I.P. Expertise. In: Kremen V. Encyclopedia of education. Yurinkom Inter, Kyiv, 2008. 
[6] Meleshko V. Peculiarities of formation of educational environment in rural school. Available at: http://library. udpu.org.ua/library_files/psuh_pedagog_probl_silsk_shkolu/15/visnuk_10.pdf. (in Ukrainian)

[7] New Ukrainian School. Conceptual basis of reformation of secondary education. Available at: https://mon.gov.ua/storage/app/media/zagalna\%20serednya/nova-ukrainska-shkola-compressed.pdf.

[8] Okon V. Introduction to general didactics. Translated from Polish: Kashkurevych L.G., Goryn N.G. Higher school, Moscow, 1990. (in Russian)

[9] Syrovetnyk N.O. Arrangement of educational environment in primary school. Volodarka, Kyiv, 2009. (in Ukrainian)

[10] Sukhomlynskyi V.O. About education. Politizdat, Moscow, 1973. (in Russian)

[11] Shapran Ju.P., Shapran O.I. Creation of innovative educational environment in the process of preparation of a future teacher. Available at: http://www.sportpedagogy.org.ua/html/journal/2010-09/10soitpt.pdf. (in Ukrainian)

Address: Svitlana Smoliyk, Lesya Ukrainka Eastern European National University, 13, Volya Avenue, Lutsk, 43025, Ukraine.

E-mail: svetlanasmoluk@gmail.com.

Received: 15.11.2017; revised: 21.03.2018.

Смодюк Світлана. Особливості формування розвивального освітнього середовища в умовах стандартизації початкової освіти України. Журнал Прикарпатського університету імені Василя Стефаника, 5 (1) (2018), 65-72.

У статті на основі вивчення наукової літератури висвітлено особливості формування освітнього середовища в сучасній початковій школі. Обгрунтовано основні складники (інформаційний, соціально-психологічний, культурно-освітній і матеріально-технічний) та компоненти інноваційного освітнього середовища початкової школи (просторовий, змістовий, комунікативний). У структурі розвивального освітнього середовища школи автором виокремлено такі функції: дидактично-виховна, інформаційно-розвивальна, координаційна, адаптивно-емоційна, соціокультурна, комунікаційна, інтеграційна, які забезпечують цілісність і системність функціонування змодельованого середовища початкової школи. Визначено основні аспекти психодого-педагогічної експертизи розвивального освітнього середовища. Виокремлено етапи діяльності усіх суб'єктів навчально-виховної взаємодії (учнів, вчителів, батьків) у предметно-змістовому функціонуванні розвивального освітнього середовища початкової школи.

Кдючові слова: розвивальне освітне середовище, початкова школа, розвиток особистості молодшого школяра, психолого-педагогічна експертиза, адаптація, соціалізація. 